\title{
リモートセンシングによる浅水域のSS・クロロフィル同時推定
}

\section{Simultaneous Estimation of SS and Chlorophyll in Shallow Water through Remote Sensing}

\author{
作野裕司 ${ }^{1} \cdot$ 神野有生 $^{2} \cdot$ 鯉㴊幸生 $^{3}$ \\ Yuji SAKUNO, Ariyo KANNO and Yukio KOIBUCHI
}

\begin{abstract}
The simultaneous estimation of SS and Chlorophyll-a (Chl.a) in shallow water through remote sensing was tried in this study. Lake Teganuma located in Chiba Prefecture was selected as a test site. Twelve spectral reflectance / Chl.a data sets were acquired using outboard boat in the lake on 28 May 2009 and 22 Oct. 2008. These data sets were related to SS or Chl.a using a simple single band or two band ratio models. As a result, a statically significant correlation was observed between "a reflectance of the simulated ALOS/AVNIR-2 Band 4 (760-890nm)" and "SS", or "reflectance ratio of the simulated AVNIR-2 band $3(610-690 \mathrm{~nm})$ and band 4" and "Chl.a". These models were validated though the ALOS/AVNIR-2 data and the buoy data set on 20 May 2008 and 28 Oct. 2009.
\end{abstract}

\section{1. はじめに}

浅水域の環境情報の把握は生物多様性の保護や管理等 にとって非常に重要である。また浅水域では時空間的な 環境変化が大きいため, 広域的・同時的な環境情報の把 握が求められている. そのため近年リモートセンシング による浅水域の環境情報（特に光学的特性）の把握に関 する研究が試みられている（神野ら，2009a，神野ら, 2009b). 一方, 浅水域の水質環境情報の把握として, 衛 星データによる水質分布把握も期待される.ただし一般 に衛星センサから外洋の植物プランクトンが持つクロロ フィル a (Chl.a）の推定は実用段階であるが，無機懸濁 物質（SS）の多い浅水域における SS・Chl.aの同時推定 は非常に難しく，専用のセンサもなかった.

そこで筆者らはSS・Chl.a とも比較的高い浅水域の宾 道湖 (島根県) や中海 (鳥取県・島根県) において, 衛 星リモートセンシングによる水質リモートセンシング研 究を行ってきた（例えば作野ら，1999；作野ら，2003）. その結果, SPOT, Landsat等に搭載されている高解像度 (数 $10 \mathrm{~m}$ 解像度) の可視・近赤外センサを使って, アオコ 発生時や一定期間のChl.aをモニタリングすることに成功 している. しかしながら, これらの結果は宾道湖・中海 のみにおける結果であり, 他の水域における実験や比較 はされていない. また, このような衛星センサは量子化 が通常 8 ビットであるため, 宍道湖・中海のような湖内 の濃度差が通常時（アオコや赤潮発生時以外）に小さい (湖内の水平濃度差は通常 SS で $10 \mathrm{mg} / 1$ 程度, Chl.aで $10 \mu \mathrm{g} / 1)$ 水域において, 濃度差の大きいデータセット (湖内の水平濃度差が SS で $50 \mathrm{mg} / 1$ 程度, Chl.a で $100 \mu \mathrm{g} / 1$ 程

\begin{tabular}{llll}
\hline 1 & 正会員 & 博 (工) & 広島大学助教大学院工学研究院 \\
2 & 正会員 & 博(環) & 山口大学助教大学院理工学研究科 \\
3 & 正会員 & 博(工) & 東京大学講師新領域創成科学研究科
\end{tabular}

度を想定）を得るためには，長期間にわたる衛星同期水 質観測が必要である。したがって同水域と同様な水質環 境の湖において，リモートセンシングによるSS・Chl.a の同時推定研究を行うには限界がある.ささらに, 高解像 度の衛星センサは海色センサのようにほぼ毎日観測され ている衛星と違い, 1 力月に 2 回程度の観測が基本であり, 雲のない画像取得とそれと同期した水質観測データを得 ることは，かなり困難であるという問題点あった。

以上のような背景から本研究では, リモートセンシン グによる浅水域における SS ・Chl.aの同時推定を目的と した. 具体的には, SS ・ Chl.aの地点間濃度差が非常に 大きく, ブイにより毎日, 複数点の水質データが得られ る環境にある手賀沼において, 実測観測した分光反射 率 /実測水質データセットを使って推定方法を検討し た。 そして最終的には衛星データとブイデータを使って 検証を行った。

\section{2. 方法およびデータ}

（1）リモートセンシングによるSS・Chl.a推定法

リモートセンシングによる水質推定において, 非常に 濁った河川河口のSS 推定や外洋におけるChl.a推定は比 較的簡単に導かれる。一般に, SS は濃度が高くなるにつ れて, 反射率が上がることが広く知られており（例えば NOVO，1989），最も基本的な SS 推定モデルとして，以 下のような 1 波長による推定が知られている.

$$
S S \propto R_{\lambda}
$$

ここで，Rは反射率， $\lambda$ は波長である．使用される波長は， 比較的波長依存性は小さいが, 一般に可視・近赤外域で は短波長よりも長波長の方がSSの推定精度が高いとされ ている。ただし近赤外域では水による顕著な光吸収があ るため，比較的反射率が高い赤波長（600〜 690nm付近） 
を使う例が多い.

一方, Chl.a推定は, 通常 Chl.a吸収の大きい青バンド と Chl.a吸収の小さい緑バンドのバンド比が使われること が多く，最も基本的な Chl.a推定モデルとして以下のよう な 2 波長 $\left(\lambda_{1}\right.$ と $\left.\lambda_{2}\right)$ 比による推定が知られている（杉 森・坂本, 1985)

$$
\text { Chl.a } \propto R_{\lambda 1} / R_{\lambda 2}
$$

ところで, SS の濃度が高く，かつ Chl.aの濃度も高い 水質環境における分光特性は実験室で詳しく調べられて いる (Han, 1997). しかし実際の水域では, 式（1）や式 （2）で使われる波長も水域によって異なり，モデルもよ り複雑になることが多い. 今回は，手賀沼においてはじ めての SS ・ Chl.a 同時推定の試みであることから，第一 段階として式（1）と式（2）の基本モデルを使用した統 計的な最適波長選択のみを試行した。

\section{(2) 研究地域と現地データ}

図-1 は研究地域の手賀沼の位置と実測した分光反射 率／水質測点およびブイ測点を示している。手賀沼は東 西約 $7 \mathrm{~km}$ ，南北約 $1 \mathrm{~km}$ の大きさで，西側が上流，東側が 下流であり, 主要流入河川は, 西方から大堀川, 大津川, 手賀川が存在する。なお，手賀沼には正式には本手賀沼 と下手賀沼があるが，本論文の研究対象は本手賀沼と する.

現地の分光反射率／水質の観測は，小型船を使って 2008 年 10 月 22 日および 2009 年 5 月 28 日の午前 11 時 \pm 1 時間程度に図-1に示した測点（Aから Fの順）で行われ た（現地調査日程は本来ALOS 観測日と同期すべきであ るが, 調査機器や人員の都合で数日異なる日となった). 分光測定機器は, 小型分光放射計MS720（EKO製，観測 波長域：350 1050nm, 波長間隔：3.3nm, 半值幅： $10 \mathrm{~nm}$ ）と標準白色板（labsphere社，約 $13 \mathrm{~cm}$ 四方の寸法 で可視・近赤外域の全波長域にわたり $99 \%$ のほほ均一な 反射率を有する，以下標準板と呼ぶ）が用いられた。観 測方法は，船上から分光計の開口部を鉛直下向きにして 水面および甲板上に置いた標準白色板の分光放射輝度を それぞれ測定した（図-2 (a) 参照)。測定条件は分光計の 開口角 $90^{\circ}$ ，測定距離約 $15 \mathrm{~cm}$ で，鉛直下向きに3 回ずつ 測定した。また最終的な反射率は 3 回の測定の平均值と した。なお，本研究の反射率は「水面直上の放射輝度」 と「標準板の放射輝度」の比と定義した。ただし，解析 には水面反射光や水面と標準板の測定時間差による影響 をできるだけ低減するために, 各地点のデータに対して, 350〜900nmの最大值と最小值で正規化した值を用いた.

SSおよびChl.aの定量は，船上から採水した表層水サン プルを持ち帰り，実験室で測定された。このうち，SSは 近赤外の吸光度を利用する Hach 社製の Hach DREL/2400

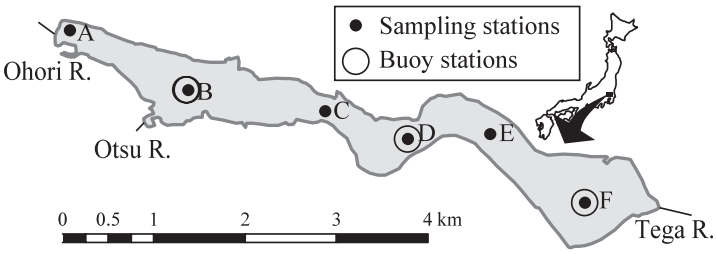

図-1 研究地域（手賀沼水質 /分光測点)

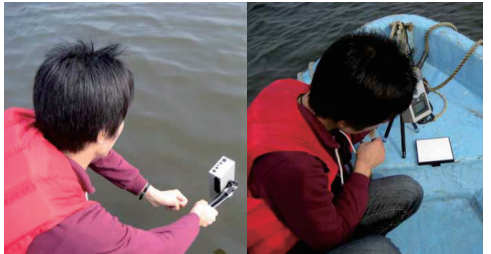

(a) Reflectance measurement

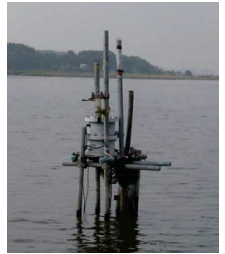

(b) Buoy station
図2 調査風景およびブイの写真

を用いて測定した。また, Chl.aはアセトン抽出・吸光光 度法で色素の吸光度を測定し，SCOR/UNESCOに基づき， Chl.aを算出する方法で測定した.

さらに実測分光反射率から導かれた SSおよびChl.aの 推定方法を使って行う衛星の検証には，図-1のB，D，F に東京大学の鯉㴊研究室が設置している，毎時間の自動 濁度（今回はSS 相当とした）・クロロフィル測定ブイ (JFEアドバンテック製COMPACT-CLW，図-2 (b) 参照) データを用いた。なお観測装置や得られる観測データの 詳細は木村・鯉㴊（2010）を参照されたい.

\section{（3）衛星データおよび反射率変換法}

実測で得られた分光反射率を衛星データで検証するた めに, 今回用いた衛星データは, ALOS (Advanced Land Observing Satellite, 通称「だいち」）に搭載された AVNIR-2 (Advanced Visible and Near Infrared Radiometer type 2) データである.AVNIR-2センサの諸元を表-1に 示す.

実際に研究に使用したAVNIR-2 データの撮影日は，分 光反射率測定実験が行われた日から数えて 1 週間以内の, 2008 年 10 月 28 日 11 時 34 分 (ポインティング角：-34.3度） 及び 2009 年 5 月 20 日（ポインティング角：0度）の 2 シ ーン（L1B2デー夕）である.

ALOSデータからの反射率計算は様々な方法が提案さ れているが，本研究では，比較的に簡単で衛星水質推定 の研究に古くから使われている以下の式（3）（Lathrop, 1991）に従った.

$$
R_{\lambda}=\pi\left(L_{s \lambda}-L_{p \lambda}\right) /\left(E S U N_{\lambda} \cos \theta_{z}\right)
$$

ここで， $R_{\lambda}$ は反射率 (無次元值)， $L_{s \lambda}$ は衛星データから 得られる放射輝度 $\left(\mathrm{W} / \mathrm{m}^{2} / \mathrm{sr} / \mu \mathrm{m}\right), L_{p \lambda}$ はパスラジアンス (主としてエアロゾル成分), ESUNは大気圈外分光放射 
表-1ＡVNIR-2センサの諸元

\begin{tabular}{c|l}
\hline $\begin{array}{c}\text { Band } \\
\text { (center) }\end{array}$ & Band1:420-500nm (460nm) \\
& Band2: 520-600nm (560nm) \\
& Band3:610-690nm (650nm) \\
& Band4:760-890nm (835nm) \\
\hline Spatial resolution & $10 \mathrm{~m}$ \\
\hline Swash & $70 \mathrm{~km}$ \\
\hline Quantization & $8 \mathrm{bit}$ \\
\hline
\end{tabular}

表-2 AVNIR-2の放射輝度変換係数

\begin{tabular}{c|c|c}
\hline Band & $a$ & $b$ \\
\hline 1 & 0.588 & 0.000 \\
\hline 2 & 0.573 & 0.000 \\
\hline 3 & 0.502 & 0.000 \\
\hline 4 & 0.835 & 0.000 \\
\hline
\end{tabular}

表-3 AVNIR-2の反射率変換パラメータ

\begin{tabular}{c|c|c}
\hline Band & $\operatorname{ESUN}\left(\mathrm{W} / \mathrm{m}^{z} / \mu \mathrm{m}\right)$ & $\cos \theta_{z}$ \\
\hline 1 & 1959 & (Oct.) \\
\cline { 1 - 1 } 2 & 1851 & 0.607 \\
& (May) \\
\hline 3 & 1546 & 0.935 \\
\hline
\end{tabular}

照度 $\left(\mathrm{W} / \mathrm{m}^{2} / \mu \mathrm{m}\right) ， \theta_{s}$ は太陽天頂角 $\left(^{\circ}\right)\left(90^{\circ}-\right.$ 太陽高度 角）である。このうち, AVNIR-2データのデジタル值 $(\mathrm{DN})$ からの $L_{s \lambda}$ 変換は, 以下のような変換式と表-2の変 換係数（ヘッダー值）に基づいて計算した.

$$
L_{\lambda}=a D N+b
$$

ここで， $a, b$ は放射輝度変換係数をそれぞれ表す。また， $L_{p \lambda}$ の推定は湖沼のリモートセンシング研究でよく用いら れる暗画素法（水域の最も暗い場所における水中からの 輝度を 0 と仮定して, 各バンドの最小值をオフセット除 去する方法）（MacFarlane and Robinson，1989）を用いた. また太陽天頂角はALOSデータのヘッダー值を, ESUN はIqbal（1983）の大気圈外分光放射照度表のAVNIR-2 デ ータの中心波長值をそれぞれ使った．以上のようにして 決定された本研究で用いたAVNIR-2データのESUNの值 を表-3に示す.さらに，ポインティング角（AVNIR-2セン サの観測角度）による補正は式（3）にポインティング角 の余弦 $(\cos )$ を乗じることにより導かれる.

\section{3. 研究結果}

\section{（1）現地水質調査結果の概要}

図-3 は調査日時における手賀沼のSS とChl.aの水平濃 度分布を示している。これょり, $\mathrm{SS}, \mathrm{Chl}$. （図-1のA, B地点付近）は低く, 中流〜下流（図-1のC, $\mathrm{D}, \mathrm{E}, \mathrm{F}$ 地点付近）で濃度が高くなる傾向がある. 小川 （1993）は1985年〜 1989年の手賀沼の年平均Chl.aを調べ,

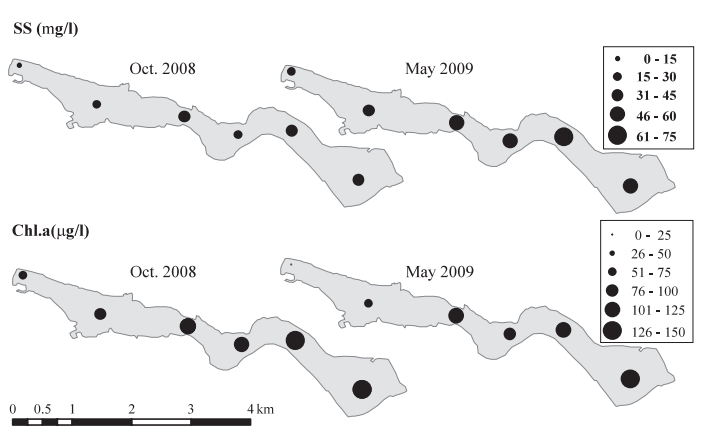

図-3 調查日のSS と Chl.aの水平分布

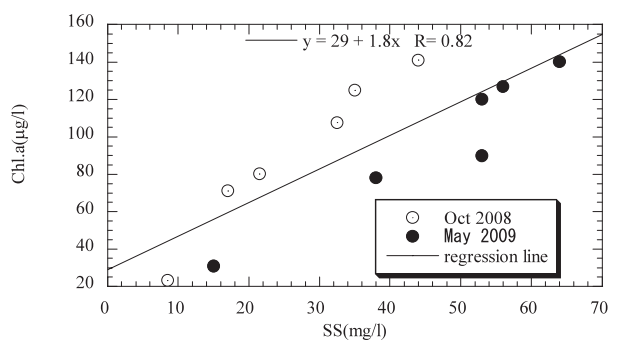

図-4 SS とChl.aの相関

経年的には下流側の方が上流側と比べて常に高い傾向を 示しており, 今回の結果はこれと一致し, 調査日は特殊 な水環境状態ではなかったと推察される. 濃度差の絶対 值としては，2008年 10 月で SSが $36 \mathrm{mg} / 1 （ 9 \sim 44 \mathrm{mg} / \mathrm{l})$, Chl.aが $11 \mu \mathrm{g} / 1 \quad(23 \sim 141 \mu \mathrm{g} / \mathrm{l}) ， 2009$ 年 5 月で SSが $49 \mathrm{mg} / 1$ (15〜 64mg/l), Chl.aが $109 \mu \mathrm{g} / 1 \quad(31 \sim 140 \mu \mathrm{g} / 1)$ で両日と も同程度あった。さらに, 図-4 はSSとChl.aの関係を示 す. 各時期はSS と Chl.aの相関は高いが, SS とChl.aの同 時推定を検証する研究としては理想的には相関が低い日 を使うべきである.しかし，今回はSS と Chl.aの相関が 低い日のデータが得られなかったため, これらのデータ を使用して研究を行った。

\section{（2）手賀沼の分光反射率特性}

図-5は手賀沼において 2 時期, 各6 点で水面直上から観 測した分光反射率測定結果である。これより，手賀沼の 分光反射率は $580 \mathrm{~nm}$ 付近（AVNIR-2 バンド2付近）を極 大として，それより短いまたは長い波長（AVNIR-2バン ド1またはバンド3付近）では，大きく吸収されている ことがわかる. 特に $670 \mathrm{~nm} \pm 50 \mathrm{~nm}$ 付近の極小と, $700 \mathrm{~nm} \pm 50 \mathrm{~nm}$ 付近の極大は, クロロフィルの吸収と散 乱・蛍光との関係で特徵的な波形を示している。このよ うな分光的な特徵は, チェサピーク湾 (Gitelson ら, 2007)，ディストリクト湖（Thiemann. and Kaufmann, 2002), 霞ヶ浦 (沖 - 安岡, 1996), 宍道湖 · 中海（作 野・松永, 2008) 等, 各地の富栄養化水域の分光特性と 同様であった。 さらに, $800 \mathrm{~nm} \pm 20 \mathrm{~nm}$ 付近（AVNIR-2 バンド 4 付近）は外洋では通常反射率が 0 として扱われ 


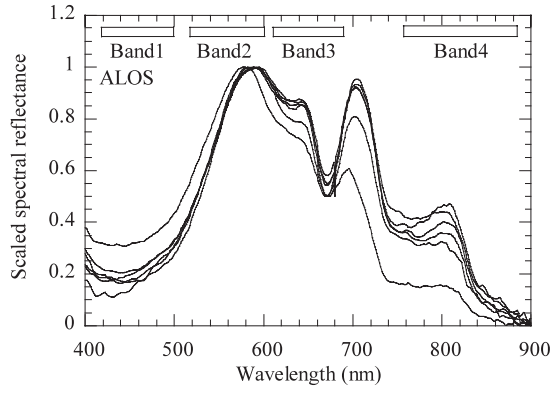

(b) 22 May 2009

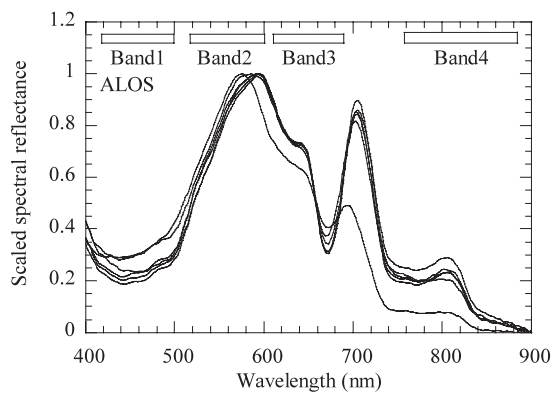

(a) 22 Oct 2008

図-5 手賀沼の実測分光反射率特性（6地点分）

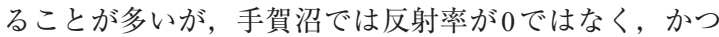
極大も見られたＡＡLOSの観測波長と比較すると，バン ド2とバンド3で極小，バンド2とバンド4で極大のピー クをとらえていることがわかる，ただし，700nm付近の 極大波長はとらえられていない.

\section{(3) 分光反射率比と SS・Chl.a の関係}

図-6は，分光反射率デー夕に基づきALOS/AVNIR-2の 単バンドおよびバンド比をシミュレートした值とSS およ びChl.aの関係（ $\mathrm{r}^{2}$ : 決定係数）を示した図である。これ より, SS はALOS Band4 相当の反射率で非常に高い $\mathrm{r}^{2}$ （0.93）を示した。これはHan（2007）が行った室内実験 の結果と一致している。一方，Chl.aは単バンドよりもバ ンド比で高い $\mathrm{r}^{2}$ （0.66）を示した。最も相関の高かった バンドの組み合わせを図-7に示すたただし，Chl.aは常用 対数をとった場合より相関が高かったため $\left(\mathrm{r}^{2}=0.74\right)$, 横軸を対数で表している．ただし，このバンド比ではSS との相関も高いため，今後 SS と Chl.aの相関が低い日時 のデータで再検証する必要があると考えられた。

\section{（4）衛星データによる検証}

図-8は，分光反射率と SS ・Chl.a の相関解析から得ら れた結果に基づき，衛星デー夕による検証結果を示して いる．ただし，図-7と図-8では反射率，反射率比のオー ダーがかなり異なっている。これは，衛星データからの 反射率変換の際に使用した暗画素法では，パスラジアン ス（大気ノイズ情報）を過剩に引いてしまうため（相関 解析には問題ないが，実測よりも小さい值となる）だと
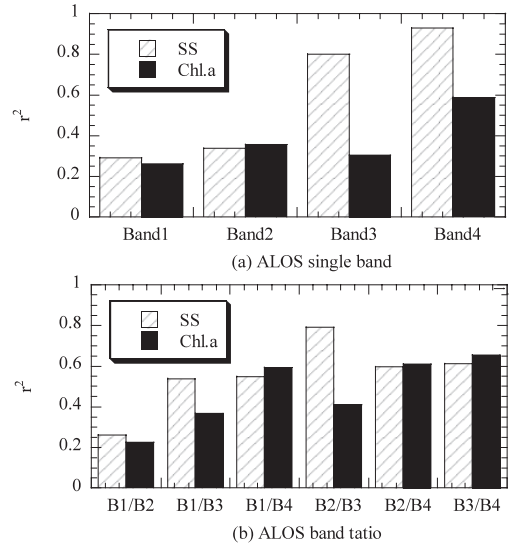

図-6 疑似ALOS データ SS およびChl.aの決定係数

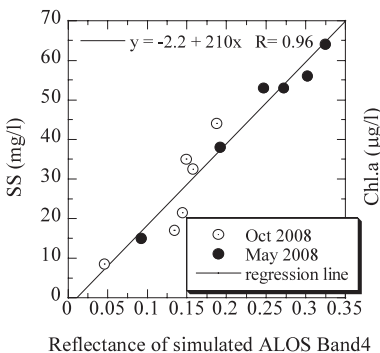

(a) SS

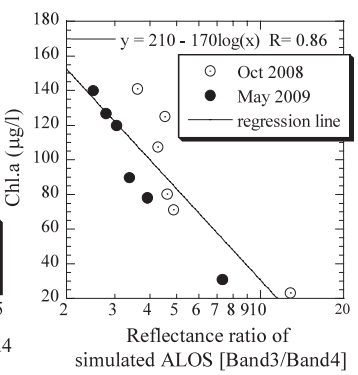

(b) Chl-a
図-7 分光反射率デー夕に基づくALOS によるSS および Chl.a推定シミュレーション結果

考えられる。また図-7と図-8では，Chl.aのオーダーもか なり異なっている，これは，船で実測したChl.aは採水後 吸光度法で測定しているのに対して，ブイのChl.aは現場 蛍光法で測定していることに起因していると考える．実 際，今回船で実測したChl.a とブイのChl.aデー夕を比較 すると平均で $70 \mu \mathrm{g} / 1$ 程度ブイのデータの方が低い值とな った。このような事項をふまえ，図-8をみると，濁度は， ALOS Band4 と, Chl.aはALOS Band3 とBand4の比でそれ ぞれ高い相関（それぞれ $\mathrm{R}=0.87$ と $\mathrm{R}=0.97 ）$ が得られた。 最終的に 2 時期の関係式（図-8）を用いてALOSから導か れた濁度とChl.a分布図を図-9と図-10 に示す。これらの 推定分布図は，実測したSS，Chl.aの分布とよく一致し ていた（図-3参照）。このように衛星デー夕を用いて， 手賀沼 SS ・ Chl.a分布の詳細（濃度の境界部等）を分か りやすく視覚化できた.

\section{4. まとめ}

本研究は，リモートセンシングによる浅水域における SS・Chl.aの同時推定を試み，以下のような結果が得ら れた。ALOS/AVNIR-2のBand4によりSSが，Band3 と Band4の比によりChl.aが，それぞれ比較的高い相関を示 し，同時推定可能であることが実測分光／水質データセ 

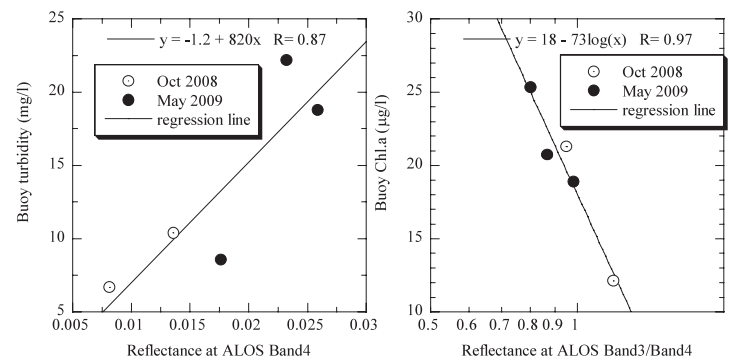

図-8 ALOSデータとブイ濁度・Chl.a検証

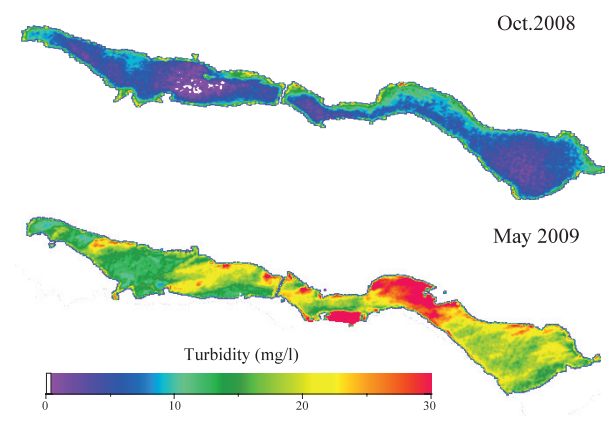

図-9ALOSデータから推定した濁度分布

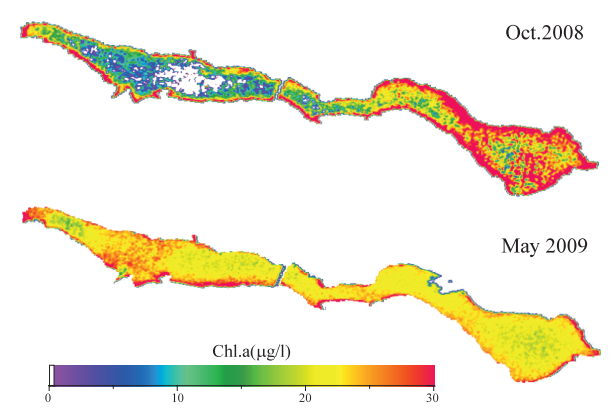

図-10 ALOS データから推定したChl.a分布

ットおよび衛星データ/ブイデータセットからそれぞれ 検証された。今後はSS と Chl.aの相関が低い場合を検証 する等, 多時期の衛星デー夕を使った安定的な SS · Chl.aの推定アルゴリズムを確立したい.

謝辞 : 本研究の一部は, 「平成 20 年度 (財) クリ夕水・ 環境科学振興財団助成」, 「平成 21 年度財団法人山陽放送 学術文化財団研究助成」,「平成 21 年度（財）中国電力技 術研究財団 試験研究 (B) 助成」(いずれも研究代表: 作野裕司）の研究の一環として行われた。記して関係機 関に深く感謝の意を表す.
参 考 文 献

神野有生・鯉㴊幸生・磯部雅彦 (2009a)：浅水域に扔ける各 種消散倸数の光学条件依存性, 土木学会論文集 B2（海岸 工学), B2-65, 1, pp.1456-1460.

神野有生・鯉渕幸生・作野裕司・磯部雅彦 (2009b)：衛星画 像を用いた水深分布予測に扔ける空間的自己相関性の利 用可能性, 水工学論文集, 第 53卷, pp.1021-1026.

木村真理・鯉渕幸生 (2010)：手賀沼のクロロフィル a ・溶存 酸素濃度の通年観測, 水工学論文集, 第 54 巻, pp.14891494.

作野裕司 - 松永恒雄 - 中山大介 - 六川修一 - 高安克己 國井秀伸・中村幹雄・山室真澄（1999）：SPOT/HRVデー 夕によるアオコ発生時の宍道湖表層クロロフィルa濃度分 布の推定, 日本リモートセンシング学会誌, 第 19 卷, 2 号, pp.20-36.

作野裕司 - 吉田武史 - 松永恒雄 - 中山大介 - 高安克巳 (2003) : 多時期Landsat/TM デー夕を用いた宾道湖・中海 のクロロフィルa濃度分布推定, 海岸工学論文集, 第 50 卷, pp. 1011-1015.

作野裕司, 松永恒雄（2008）: 分光反射率デー夕を用いた汽水 湖における高クロロフィルa濃度の推定精度評価, 環境工 学研究論文集, Vol.45, pp.113-119.

杉森康宏・坂本 亘 (1985): 海洋環境光学, 東海大学出版会, $356 \mathrm{p}$.

沖 一雄 - 安岡善文 (1996)：高濃度水域に打ける近赤外波長 带を含む二波長によるクロロフィルa推定モデルの作成, 日本リモートセンシング学会誌, 第16卷, 4号, pp. 1-9.

山田安彦・白鳥孝治・立本英機編（1993）：印旛沼・手賀沼 水環境一の提言, 古今書院, $167 \mathrm{p}$.

Gitelson, A. A., Schalles, J. F., Hladik, C.m. (2007) : Remote chlorophyll-a retrieval in turbid, productivite estuaries: Chesapeak Bay case study, Rem. Sens. Environ., Vol.109, pp.464-472.

Han, L. (1997) : Spectral reflectance with varying suspended sedimanet concentrations in clear and algae-laden waters, PE \& RS, Vol.63, No.6, pp.701-705.

Iqbal, M. (1983) : An introduction to solor radiation, Academic Press, 390p.

Lathrop, R.G., Lillesand, T.M., and Yandell, B.S. (1991) : Testing the utility of simple multi-date thematic mapper calibration algorithms for monitoring turbid inland waters, International Journal of Remote Sensing, Vol.12, pp.2045-2063.

MacFarlane, N. and Robinson, I. S. (1984) : Atmospheric correction of LANDSAT MSS data for amultidate suspended sediment algorithm. International Journal of Remote Sensing, Vol.5, pp.561-576.

Novo, E. M. M., Hansom, J. D., and Curran, P. J. (1989) : The effect of sediment type on the relationship between reflectance and suspended sediment concentration. International Journal of Remote Sensing, Vol.10, pp.1283-1289.

Thiemann, S. and Kaufmann, H. (2002) : Lake water quality monitoring using hyperspectral airborne data - a semiempirical multisensor and multitemporal approach for the Mecklenburg Lake District, Germany, Rem. Sens. Environ., Vol.81, pp.228237. 